\title{
Phylogenetic Analyses of the Genus Hymenobacter and Description of Siccationidurans gen. nov., and Parahymenobacter gen. nov
}

Gundlapally Sathyanarayana Reddy*

CSIR-Centre for Cellular and Molecular Biology, Uppal Road, Hyderabad-500 007, India

\begin{abstract}
Phylogenetic analyses of 26 species of the genus Hymenobacter based on the $16 \mathrm{~S}$ rRNA gene sequences, resulted in polyphyletic clustering with three major groups, arbitrarily named as Clade1, Clade2 and Clade3. Delineation of Clade1 and Clade3 from Clade2 was supported by robust clustering and high bootstrap values of more than $90 \%$ and $100 \%$ in all the phylogenetic methods. 16S rRNA gene sequence similarity shared by Clade1 and Clade 2 was 88 to $93 \%$, Clade 1 and Clade 3 was 88 to $91 \%$ and Clade2 and Clade 3 was 89 to $92 \%$. Based on robust phylogenetic clustering, less than $93.0 \%$ sequence similarity, unique in silico restriction patterns, presence of distinct signature nucleotides and signature motifs in their 16S rRNA gene sequences, two more genera were carved to accommodate species of Clade1 and Clade3. The name Hymenobacter, sensu stricto, was retained to represent 17 species of Clade2. For members of Clade1 and Clade3, the names Siccationidurans gen. nov. and Parahymenobacter gen. nov. were proposed, respectively, and species belonging to Clade1 and Clade3 were transferred to their respective genera. The genera Hymenobacter (sensu stricto), Siccationidurans gen. nov. and Parahymenobacter gen. nov. contained the signature motifs AAGGCTTTCTGAGTCGTAAA (414-432), TGACGGTACCTGAGGAATAA (480-499) and ATTAATACCGCATAACACT (168-185) in their 16S rRNA gene sequences, respectively. Further, the genus Hymenobacter was emended and proposed a more acceptable genus description.
\end{abstract}

Keywords: Phylogeny; 16S rRNA gene sequence; Siccationidurans gen. nov.; Parahymenobacter gen. nov.; Hymenobacter

\section{Introduction}

Analysis and validation of $16 \mathrm{~S}$ rRNA gene sequence based phylogeny is the basis for prokaryotic systematics [1,2]. In this context, it is worth mentioning that, based on $16 \mathrm{~S}$ rRNA gene sequence analyses, five distinct phylogenetic groups within the genus Bacillus [3], two novel orders, Solirubrobacterales and Thermoleophilales [4], and a new hierarchic classification structure for the actinomycete line of descent [5] were proposed and the phylogenetic affiliation of the genus pseudomonads was assessed [6]. In congruence with these, to take few examples, several novel genera, such as Solibacillus [7] and Planomicrobium [8], were created on the basis of their 16S rRNA gene sequence. Present work is focused on evaluating the internal features of the 16S rRNA gene sequences of the genus Hymenobacter.

The genus Hymenobacter, which belongs to the phylum Bacteroidetes, order Sphingobacteriales and family Cytophagaceae, was described by Hirsch et al. [9] and subsequently emended by Buczolits et al. [10]. The genus accommodates species that are strictly aerobic, Gram-negative, rod-shaped, non-motile, red-pigmented and contain menaquinone $\mathrm{MK}-7$, fatty acids iso- $\mathrm{C}_{15: 0}$, anteiso- $\mathrm{C}_{15: 0}, \mathrm{C}_{16: 1} \omega 5 \mathrm{c}$, summed feature $3\left(\mathrm{C}_{16: 1} \omega 7 \mathrm{c} /\right.$ iso- $\left.\mathrm{C}_{15: 0} 2-\mathrm{OH}\right)$ and summed feature 4 (iso- $\mathrm{C}_{17: 1}$ I/anteiso- $\mathrm{C}_{16: 1}$ B) with high DNA G+C content of 55 to 65 (mol \%). The genus presently contains 26 species, including recently described species $[11,12]$, which were isolated from various ecological niches. Klassen and Foght [13] and Reddy and Garcia-Pichel [12], in their recent study, discussed the polyphyletic clustering of all species into three major clades, (Clade1, Clade2 and Clade3), based on 16S rRNA gene sequence. Clade1, Clade2 and Clade3 encompassed seven, seventeen and two species, respectively. Exploration of the internal features of the 16S rRNA gene sequences of 26 species of the genus Hymenobacter warranted the creation of two novel genera to accommodate species that belong to Clade1 and Clade3; for which the names Siccationidurans gen. nov. and Parahymenobacter gen. nov. are proposed. Hymenobacter soli $\mathrm{PB} 17^{\mathrm{T}}=\mathrm{LMG} 24240^{\mathrm{T}}=\mathrm{KCTC} 12607^{\mathrm{T}}$, the oldest species belonging to Clade1, was elevated to the status of type species of the genus Siccationidurans and named as Siccationidurans soli $\mathrm{PB} 17^{\mathrm{T}}=\mathrm{LMG} 24240^{\mathrm{T}}=\mathrm{KCTC} 12607^{\mathrm{T}}$. Similarly, Hymenobacter ocellatus
Myx $2105^{\mathrm{T}}=\mathrm{Txo}^{\mathrm{T}}=\mathrm{DSM} 11117^{\mathrm{T}}=\mathrm{LMG} 21874^{\mathrm{T}}$ was transferred to the genus Parahymenobacter as Parahymenobacter ocellatus Myx $2105^{\mathrm{T}}=\mathrm{Txo}^{\mathrm{T}}=\mathrm{DSM} \quad 11117^{\mathrm{T}}=\mathrm{LMG} 21874^{\mathrm{T}}$ and designated as the type species. Further, the genus Hymenobacter needs be emended as Hirsh et al. [9] and Buczolits et al. [10] had included strain specific characteristics, some of which were not characterized in all the species, as in the case of spermidines. With the identification of signature nucleotides and signature motifs, a more acceptable genus description is proposed.

\section{Methods}

\section{Phylogenetic analyses}

Almost full length 16S rRNA gene sequences belonging to species of the genera Hymenobacter, Pontibacter, Adhaeribacter and Cytophaga, were downloaded from the NCBI data base (http://www.ncbi.nlm.nih. gov). For phylogenetic analyses, all the sequences were aligned using CLUSTAL-W, the multiple alignment program option of MEGA5 [14]. Evolutionary distances between all species were computed using Kimura 2-model [15], present in the distance option of MEGA5. Phylogenetic trees were constructed using four different tree-making algorithms (Neighbor-Joining, Minimum Evolution, Maximum Likelihood and Maximum parsimony analysis), using MEGA5. Bootstrap analyses in all the phylogenetic trees were performed employing 1000 replicate data sets in order to assess the stability among clades recovered in the phylogenetic tree.

*Corresponding author: Gundlapally Sathyanarayana Reddy, CSIR-Centre for Cellular and Molecular Biology, Uppal Road, Hyderabad-500 007, India, Tel: 91-4027192509; E-mail: rukmagsn@gmail.com

Received September 04, 2013; Accepted October 17, 2013; Published October 25,2013

Citation: Sathyanarayana Reddy G (2013) Phylogenetic Analyses of the Genus Hymenobacter and Description of Siccationidurans gen. nov., and Parahymenobacter gen. nov. J Phylogen Evolution Biol 1: 122. doi:10.4172/2329-9002.1000122

Copyright: (c) 2013 Sathyanarayana Reddy G. This is an open-access article distributed under the terms of the Creative Commons Attribution License, which permits unrestricted use, distribution, and reproduction in any medium, provided the original author and source are credited. 


\section{Restriction enzyme analysis}

Fifteen Type II Restriction enzymes (Table S1) were considered for generating in silico restriction patterns. For this purpose, Restriction Mapper Version 3 (http://restrictionmapper.org) was used to map the restriction patterns of 26 Hymenobacter species (sequence length from 118 to 1460; with respect to E. coli $16 \mathrm{~S}$ rRNA gene sequence with accession number J01695), employed for construction of phylogenetic framework. These restriction patterns were analyzed and a consensus pattern was determined for each species.

\section{Cluster analysis for restriction profile}

For cluster analyses NTSYSpcs, Numerical Taxonomy System and multivariate statistical package, software version 2.2 [16] was used. Initially, data for restriction patterns generated in silico, using different type II restriction enzymes, was entered in the form of 1 (presence of a band) and 0 (absence of a band) in NTedit 1.1. The similarity matrix was generated using SimQual of similarity, the dendogram was constructed with Shan of Clustering option and the trees were viewed with Graphics options present in NTSYSpc.

\section{Signature nucleotides}

Signature nucleotides that are highly conserved in every sequence or in a specific clade were identified in the alignment file that was generated using MEGA5 [14]. Every single signature nucleotide found was then positioned on the secondary structure of $16 \mathrm{~S}$ rRNA molecule of E. coli (accession number J01695; obtained from (http://www.rna. icmb.utexas.edu/SIM/4C/mfold_Eval/accuracy/16s.acc.detailed). This analysis allowed interpretation of signatures found in terms of single or double compensatory mutations in helices of the secondary structure. Compensatory mutations are two nucleotides that stabilize a stem in the secondary structure (such as $\mathrm{G}-\mathrm{C}$ or $\mathrm{A}-\mathrm{T}$ ), and are mutated (for example to $\mathrm{C}-\mathrm{G}$ or T-A) in specific taxa.

\section{Signatures motifs}

Signatures motifs were identified in each of the species data set using the online MEME program [17]. Seven, seventeen and two sequence data sets of Clade1, Clade2 and Clade3, respectively, belonging to the genus Hymenobacter were submitted group wise in MEME program version 4.6.1 (http://meme.nbcr.net/meme/cgi-bin/ meme.cgi). In order to obtain maximum number of motifs, the default setting was modified from 3 to 10 motifs. The default value of motif width was also modified and re-set between 10 and 20. Each of the 10 signatures was checked for its frequency of occurrence among a particular Hymenobacter species. The signatures which did not appear in other clades of the Hymenobacter species were considered as unique. BLAST sequence similarity search against the NCBI database http:// www.ncbi.nlm.nih.gov [18] and EzTaxon [19], was carried out for these signatures to check their uniqueness.

\section{Results and Discussion}

Twenty six, seven and four species of the genera Hymenobacter [9,10], Pontibacter [20] and Adhaeribacter [21], respectively, were aligned using CLUSTAL W option of MEGA5 [14]. The aligned 16S rRNA gene sequences exhibited two hyper variable regions spanning from 72 to 115 (33 nucleotides long) and 180 to 195 (15 nucleotides long) (with respect to E. coli $16 \mathrm{~S}$ rRNA gene sequence; accession number J01695) and mapped V1 and V2 regions, respectively [22,23]. Most of the variation in 16S rRNA gene sequences of species of the genera was contributed by these two regions and rest of the variation is randomly distributed in the entire region of rRNA gene sequences.
To avoid the 'Felsenstein zone' (i.e. retrieving a wrong tree even if it has high bootstrap values), phylogenetic analyses [24] were performed with different phylogenetic methods. For this purpose, Neighbor joining (NJ), Minimum evolution (ME), Maximum likelihood (ML) and Maximum parsimony (MP) options were used to generate the trees. Topology of Neighbor joining (NJ) and Minimum evolution (ME) trees indicated that species of the genera Pontibacter [20] and Adhaeribacter [21] formed coherent monophyletic clusters with bootstrap values above $85 \%$ (Figure 1 and S1). In case of Maximum likelihood (ML) and Maximum parsimony analyses, species of the genera Pontibacter appeared as a monophyletic clade, but Adhaeribacter showed a split in clustering, wherein Adhaeribacter terreus [25] emerged as a separate branch from the main cluster represented by rest of the species (Figure S2 and S3). Species of the genus Hymenobacter [9] were highly divergent, polyphyletic in all the methods and formed three major clusters, named arbitrarily as Clade1, Clade2 and Clade3 (Figures 1 and S1-S3), which are deeply rooted from each other and are sister clades emerging from a common ancestor. Further, delineation of Clade1 and Clade3 from Clade2 was supported by robust clustering and high bootstrap values of more than $90 \%$ and $100 \%$, respectively in all the phylogenetic methods (Figures 1 and S1-S3), and the present clustering of species of the genus Hymenobacter is consistent with previous studies [12,13, 26-29].

Evolutionary distances, based on 16S rRNA gene sequence, as calculated using Kimura 2-parameter model [15], were found to be 90 to $97 \%, 92$ to $99 \%$ and $95 \%$, respectively, among species belonging to Clade1, Clade2 and Clade3 of the genus Hymenobacter. 16S rRNA gene

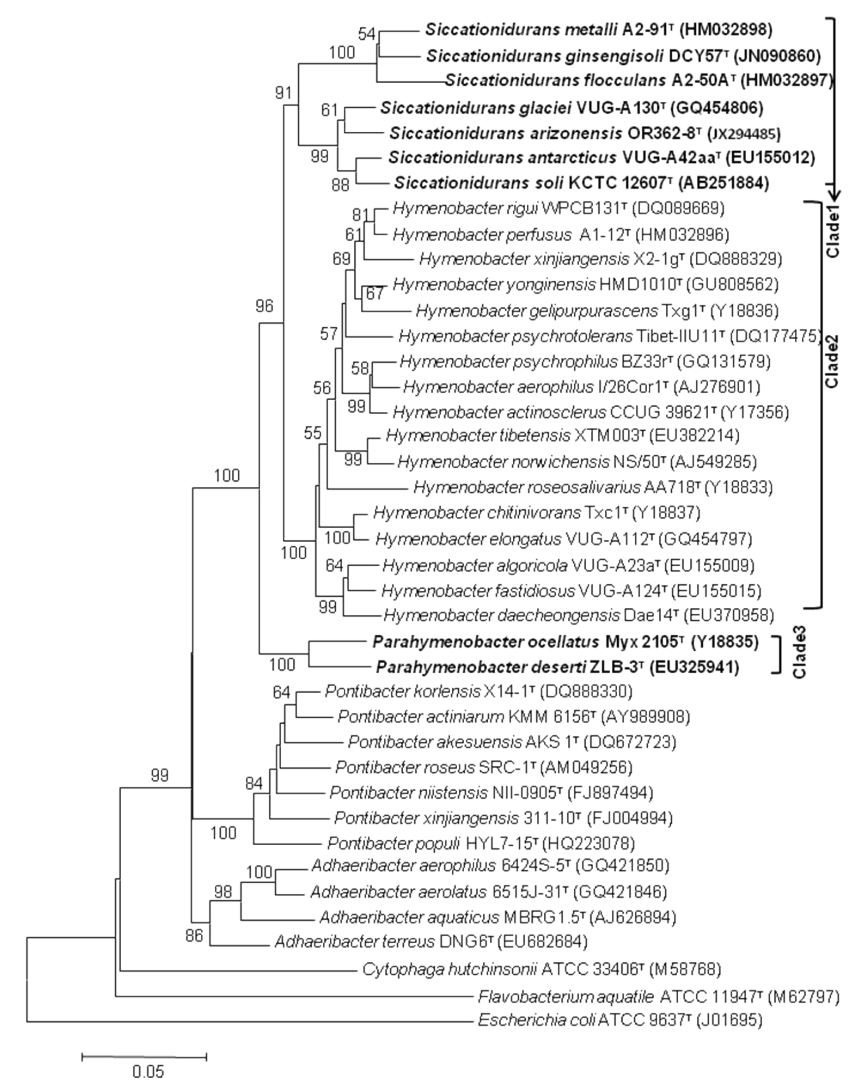

Figure 1: A Neighbour-joining tree based on 16S rRNA gene sequences showing the phylogenetic relationship between the genera Siccationidurans gen. nov., Hymenobacter, Parahymenobacter gen. nov., and other related genera of the family Cytophagaceae. Bootstrap values (expressed as percentages of 1000 replications) greater than $50 \%$ are indicated at the nodes. 
sequence similarity shared by Cladel and Clade 2 is 88 to $93 \%$, Clade 1 and Clade 3 is 88 to $91 \%$ and Clade 2 and Clade 3 is 89 to $92 \%$ (Table S2), significantly larger than the $\sim 95 \%$ threshold typically used to split genera [30]. The robust clustering of three clades belonging to the genus Hymenobacter with high bootstrap values (in all the four phylogenetic methods employed) (Figures 1 and S1-S4), and aggregate sequence similarity of less than $93 \%$ among three clades (Clade1, Clade 2 and Clade3), supported the proposal to assign species of Clade1 and Clade3 to a higher taxonomic rank [31]. The above proposal is significantly supported by the genera Adhaeribacter [21] and Pontibacter [20], as they also share a $16 \mathrm{~S}$ rRNA gene sequence similarity of 88 to $92 \%$ and form a coherent cluster with high bootstrap values (Figures 1 and S1S3).

In addition, the number of nucleotides conserved in the $16 \mathrm{~S}$ rRNA gene of Gram-negative bacteria is more than that of Gram-positive bacteria. Gram-negative and Gram-positive bacteria contain 713/1542 and 568/1542 nucleotides, respectively, in the highly conserved regions [30], and a total of 145/1542 (9.4\%) more nucleotides are conserved in Gram-negative bacteria. Under these circumstances, the difference of 88 to $93 \%$ among species of Clade1, Clade2 and Clade3, being Gramnegative by virtue, belonging to the genus Hymenobacter, is huge and demands the creation of new genera [30], since earlier the genera were carved with $>92 \% 16 \mathrm{~S}$ rRNA gene sequence similarity [7,8,32-34]. The main impediment is the lack of diagnostic phenotypic differences. However, Stackebrandt et al. [5], Ash et al. [3], Reddy and Garcia-Pichel [4] and Ivanova et al. [31] created the genera, families and orders based only on the presence of unique signatures in 16S rRNA gene sequences, further implicating that the phylogenetic evidence alone is sufficient to create a higher taxonomic rank. However, polyphasic taxonomy emphasizes the significance of consensus between phenotypic and genotypic characteristics [35-38], in delineation of taxa. But several phenotypic markers are variable and dependent on environmental cues. For instance, the expression of characteristics that serve in genus description, such as cell morphology [39-42], enzymes [43,44], fatty acids [45,46] menaquinones [47-49], lipids [50-53] and peptidoglycan [54-57], depend on the growth conditions. Further, discrepancies in the above traits were well documented among species of several genera $[58,59]$, and thus hamper in drawing congruence between phylogeny and expressed characteristics. On the other hand, $16 \mathrm{~S}$ rDNA sequence based phylogeny has been serving as a stable trait in delineation of several taxa, and is considered as the basis in creation of numerous taxanomic groups, as mentioned earlier [4,5]. However, the importance of other polyphasic characteristics cannot be discounted, but should be considered as significant auxiliary and descriptive, rather than distinctive markers per se. In the present study, it is unambiguously established by phylogenetic analyses that the genera, Siccationidurans gen. nov. and Parahymenobacter gen. nov., are distinctly different from already described nearest genera. Therefore, phenotypic traits were considered in the description of genera (please refer to the genus description).

Because of the low 16S rRNA sequence similarity of less than $93 \%$, it was assumed that the restriction patterns would be different for the three clades of the genus Hymenobacter. In the present study, fifteen type II restriction enzymes (Table S1) were used in silico and they revealed differences in the fragmentation patterns. Restriction sites for AluI, BfaI, BstUI, DpnI, HaeIII, HhaI, MboI, MseI, MspI, RsaI and Sau3AI (11 enzymes) occurred with a frequency of 2-10, resulting in 3-11 fragments. The enzyme SmaI gave 2 restriction fragments of length 1280 and 48 (positions are with respect to $H$. arizonensis), restriction sites for the enzymes BamHI and EcoRI were not found in any of the 26 sequences studied and HindIII had a single cut in a single species; the Hymenobacter psychrophilus. Thus the enzymes, BamHI, EcoRI, HindIII and SmaI are less informative and serve no purpose. In spite of low frequency, HindIII can still be used to distinguish the species, Hymenobacter psychrophilus and SmaI can be combined with other enzymes to distinguish the members of Hymenobacter [9]. The enzymes, AluI, BfaI, BstUI, HaeIII, HhaI, MseI, MspI, RsaI and SmaI generated 31 out of 113 common fragments in all the 26 species and can serve as markers to identify the members of this group. Interestingly, the enzymes DpnI, MboI, Sau3A1, HaeIII and RsaI distinguish the species of Clade1 from other Clades in that DpnI, MboI, Sau3A1 generated a fragment size of 209 in 19 species of Clade2 and Clade3, but not in Clade1. Similarly, HaeIII created a fragment size of 321 in species of Clade2 and Clade3, but not in Clade1 and RsaI produced a fragment of 556 in 6/7 species of Clade1 and lacks the fragment size of 645. Clade3 can be differentiated from Clade1 and Clade2 using AluI, which generates a fragment size of 515 in all, but Clade1 and in Clade2, the fragment is produced only in $6 / 17$ species. Thus, the enzymes, $D p n I$, MboI, HaeIII, Sau3A1 and RsaI can be used as markers to distinguish the species of the three clades. Approximately, 113 fragments generated among 26 species of the genus Hymenobacter were used in dendogram construction and the species of Clade1, Clade2 and Clade 3 delineated at a similarity coefficient value of $80 \%, 81 \%$ and $86.5 \%$, respectively (Figure S4). Thus, the in silico restriction patterns resulted in the differentiation of three clades belonging to the genus Hymenobacter and their robust clustering into three Clades, congruent to the $16 \mathrm{~S}$ rRNA gene sequence based phylogeny further strengthened the need to create two more genera to accommodate the species of Clade1 and Clade3.

Further evidence in support of awarding genus status to members of Clades 1 and 3 comes from the analyses based on comparison of baseto-base 16S rRNA gene sequences. Species of Clade1 are characterized by the presence of nucleotides G-C (294-303), G (306), G-C (317336), A (408), T-A (419-424), C (427), T (434), G-C/C-G (462-476), T (477), A (658), A (728), T (747), C-G/G-C (897-902), G (1285) and A (1286) (20 nucleotides), of which nucleotides at positions 306, 317$336,408,419-424,427,658,728,747$ are unique (Table 1). Species of Clade2 contain C (256), C (268), C-G (294-303), T-A (317-336), C-G (419-424), C (441), G (493), C-G (897-902), A (903), A (1285) (14 positions), of which nucleotides at positions 294-303, 441, 493 are distinctive. Similarly Clade3 possesses G (127), G (128), T (131), T (140), T (165), A (206), A (215), C (219), A (231), C (233), C (234), G-C (294-303), C (304), T-A (317-336), G (490), T (492), C (594), T (833), C (854), G-C (897-902), G (1019), C (1174), A (1275), C (1364) (27 positions). Positions 127, 128, 131, 140, 1364 and the absence of nucleotide at 462 differentiate Clade 3 from Clade1 and Clade2 (Table 1). Close to 48 signature nucleotides were identified at various positions (Table 1), of which 20, 14 and 27 were highly conserved among Clade1, Clade2 and Clade3, respectively. There is no limit to the number of signature nucleotides in carving new genera as Dai et al. [60], identified a difference of just 2 signature nucleotides between the genera Planococcus and Planomicrobium. Further, based on the difference of 13 unique nucleotides, the genus Sphingosinicella, without strong phenotypic support, was dissected from Sphingomonas [61]. Thus, the presence of above signature nucleotides not only distinguishes between the three Clades, but also serves as additional evidence in carving the genera.

Splitting of the genus Hymenobacter [9] into three genera was further substantiated by unique signature motifs. Out of 19 signatures motifs identified among the three clades of the genus Hymeno- 
Citation: Sathyanarayana Reddy G (2013) Phylogenetic Analyses of the Genus Hymenobacter and Description of Siccationidurans gen. nov., and Parahymenobacter gen. nov. J Phylogen Evolution Biol 1: 122. doi:10.4172/2329-9002.1000122

Page 4 of 9

\begin{tabular}{|c|c|c|c|c|c|c|c|c|c|c|c|c|c|c|c|c|c|}
\hline & & \multicolumn{16}{|c|}{ Position of the nucleotide } \\
\hline & Species & 127 & 128 & 131 & 140 & 165 & 206 & 215 & 219 & 223 & 231 & 233 & 234 & 256 & 268 & 294 & 303 \\
\hline \multirow{8}{*}{ Clade1 } & E. coli (J01695) & G & G & A & $\mathrm{T}$ & G & C & C & $\mathrm{T}$ & A & $\mathrm{T}$ & C & C & $\mathrm{T}$ & $\mathrm{T}$ & T & A \\
\hline & S. arizonensis (JX294485) & A & C & C & $T$ & C & G & $T$ & $T$ & A & G & G & $T$ & G & C & G & c \\
\hline & S. glaciei (GQ454806) & G & C & C & A & C & G & $\mathrm{T}$ & $\mathrm{T}$ & $\mathrm{T}$ & G & G & C & C & C & G & C \\
\hline & S. antarcticus (EU155012) & A & C & C & A & C & T & $\mathrm{T}$ & $\mathrm{T}$ & T & G & G & T & A & $\mathrm{T}$ & G & c \\
\hline & S. soli (AB251884) & A & C & C & A & C & $\mathrm{T}$ & T & T & $\mathrm{T}$ & G & G & $\mathrm{T}$ & C & C & G & c \\
\hline & S. metalli (HM032898) & A & C & C & A & C & $\mathrm{T}$ & $\mathrm{T}$ & $\mathrm{T}$ & $\mathrm{T}$ & G & G & $\mathrm{T}$ & $T$ & $\mathrm{~T}$ & G & C \\
\hline & S. flocculans (HM032897) & A & C & C & G & C & G & T & G & C & G & G & $\mathrm{T}$ & T & $\mathrm{T}$ & G & C \\
\hline & S. ginsengisoli (JN090860) & A & C & C & A & C & A & $T$ & $T$ & $T$ & G & G & $T$ & $T$ & $T$ & G & c \\
\hline \multirow{17}{*}{ Clade2 } & H. actinosclerus (Y17356) & A & C & C & A & C & $\mathrm{T}$ & $\mathrm{T}$ & $\mathrm{T}$ & $\mathrm{T}$ & G & G & $\mathrm{T}$ & C & C & c & G \\
\hline & H. aerophilus (AJ276901) & A & C & $\mathrm{T}$ & A & $\mathrm{T}$ & $\mathrm{T}$ & T & $\mathrm{T}$ & $\mathrm{T}$ & A & G & $\mathrm{T}$ & C & C & c & G \\
\hline & H. algoricola (EU155009) & A & C & C & A & C & A & $T$ & $T$ & $T$ & G & G & $\mathrm{T}$ & C & C & C & G \\
\hline & H. chitinivorans (Y18837) & A & C & C & A & C & $\mathrm{T}$ & $\mathrm{T}$ & $\mathrm{T}$ & $\mathrm{T}$ & G & G & $\mathrm{T}$ & C & C & c & G \\
\hline & H. daecheongensis (EU370958) & A & C & C & A & C & G & $\mathrm{T}$ & $\mathrm{T}$ & $\mathrm{T}$ & G & G & $\mathrm{T}$ & C & C & c & G \\
\hline & H. elongatus (GQ454797) & A & C & C & A & C & $T$ & $T$ & $T$ & $T$ & G & G & $T$ & C & C & c & G \\
\hline & H. fastidiosus (EU155015) & A & C & C & A & C & G & $\mathrm{T}$ & $\mathrm{T}$ & $\mathrm{T}$ & G & G & $\mathrm{T}$ & C & C & c & G \\
\hline & H. gelipurpurascens (Y18836) & A & C & C & G & C & G & $\mathrm{T}$ & $\mathrm{T}$ & C & G & G & $\mathrm{T}$ & C & C & G & c \\
\hline & H. norwichensis (AJ549285) & A & C & C & A & C & $T$ & $T$ & $T$ & $T$ & G & G & $T$ & C & C & c & G \\
\hline & H. roseosalivarius (Y18833) & A & C & C & C & C & $\mathrm{T}$ & $\mathrm{T}$ & $\mathrm{T}$ & G & G & G & $\mathrm{T}$ & C & C & c & G \\
\hline & H. rigui (DQ089669) & A & $\mathrm{C}$ & C & G & C & G & $T$ & $T$ & C & G & G & $T$ & C & C & $c$ & $G$ \\
\hline & H. psychrophilus (GQ131579) & A & C & C & A & C & $\mathrm{T}$ & $\mathrm{T}$ & T & $\mathrm{T}$ & G & G & $\mathrm{T}$ & C & C & c & $G$ \\
\hline & H. psychrotolerans (DQ177475) & A & C & C & G & C & G & $\mathrm{T}$ & $\mathrm{T}$ & C & G & G & $\mathrm{T}$ & C & C & c & G \\
\hline & H. perfusus (HM032896) & A & $\mathrm{C}$ & C & G & C & $T$ & $T$ & $T$ & C & G & G & $T$ & C & C & $c$ & G \\
\hline & H. xinjiangensis (DQ888329) & A & C & C & G & C & T & $\mathrm{T}$ & $\mathrm{T}$ & C & G & G & $\mathrm{T}$ & C & C & c & G \\
\hline & H. yonginensis (GU808562) & A & C & C & A & C & $\mathrm{T}$ & $\mathrm{T}$ & $\mathrm{T}$ & $\mathrm{T}$ & G & G & $\mathrm{T}$ & C & C & c & G \\
\hline & H. tibetensis (EU382214) & A & C & C & G & C & T & $\mathrm{T}$ & T & C & G & G & T & C & C & c & $G$ \\
\hline \multirow{5}{*}{ Clade3 } & Ph. deserti (EU325941) & G & G & $\mathbf{T}$ & $T$ & $T$ & A & A & C & A & A & C & C & C & C & G & C \\
\hline & Ph. ocellatus (Y18835) & G & G & $\mathbf{T}$ & $T$ & $T$ & A & A & C & A & A & C & C & $\mathrm{T}$ & $T$ & G & c \\
\hline & & \multicolumn{16}{|c|}{ Position of the nucleotide } \\
\hline & Species & 304 & 306 & 317 & 336 & 408 & 419 & 424 & 427 & 434 & 441 & 462 & 476 & 477 & 490 & 492 & 493 \\
\hline & E. coli (J01695) & $\mathrm{T}$ & A & $\mathrm{T}$ & A & A & C & G & $\mathrm{T}$ & $\mathbf{T}$ & A & G & $\mathrm{T}$ & C & C & C & A \\
\hline \multirow{7}{*}{ Clade1 } & S. arizonensis (JX294485) & $T$ & G & G & C & A & $\mathbf{T}$ & A & C & $T$ & G & $\mathbf{G}$ & C & C & $T$ & G & $\mathrm{T}$ \\
\hline & S. glaciei (GQ454806) & $T$ & G & G & C & A & $\mathbf{T}$ & A & C & $T$ & G & $\mathbf{G}$ & C & $T$ & $T$ & G & $\mathrm{T}$ \\
\hline & S. antarcticus (EU155012) & $T$ & G & G & C & A & $\mathbf{T}$ & A & C & $\mathbf{T}$ & A & G & C & $T$ & $T$ & A & $\mathrm{T}$ \\
\hline & S. soli (AB251884) & $T$ & G & G & C & A & $\mathbf{T}$ & A & C & $\mathbf{T}$ & G & G & C & $T$ & $\mathrm{~T}$ & G & $\mathrm{T}$ \\
\hline & S. metalli (HM032898) & $T$ & G & G & C & A & $\mathbf{T}$ & A & C & $\mathbf{T}$ & G & C & $\mathbf{G}$ & $T$ & $T$ & C & A \\
\hline & S. flocculans (HM032897) & $T$ & G & G & C & A & $T$ & A & C & $T$ & G & C & G & $T$ & $T$ & C & A \\
\hline & S. ginsengisoli (JN090860) & $T$ & G & G & C & A & $\mathbf{T}$ & A & C & $T$ & G & C & G & $T$ & $\mathrm{~T}$ & C & A \\
\hline \multirow{17}{*}{ Clade2 } & H. actinosclerus (Y17356) & $T$ & A & $T$ & $A$ & $\mathrm{C}$ & c & $\mathbf{G}$ & $T$ & G & C & - & A & C & $T$ & A & G \\
\hline & H. aerophilus (AJ276901) & $T$ & $\mathrm{D}$ & $T$ & $A$ & C & c & G & $T$ & G & C & - & A & C & $T$ & A & G \\
\hline & H. algoricola (EU155009) & $\mathrm{T}$ & A & $T$ & $A$ & C & C & $\boldsymbol{G}$ & $\mathrm{T}$ & G & C & - & A & A & $\mathrm{T}$ & A & G \\
\hline & H. chitinivorans (Y18837) & $T$ & A & $T$ & $A$ & C & $c$ & G & $T$ & G & C & - & A & A & $T$ & A & G \\
\hline & H. daecheongensis (EU370958) & $T$ & A & $T$ & $A$ & $\mathrm{C}$ & $c$ & G & $T$ & G & C & - & A & A & $T$ & A & G \\
\hline & H. elongatus (GQ454797) & $T$ & A & $T$ & $A$ & $A$ & $C$ & G & $T$ & $\mathrm{~T}$ & C & - & A & A & $\mathrm{T}$ & A & G \\
\hline & H. fastidiosus (EU155015) & $T$ & A & $T$ & $A$ & $\mathrm{C}$ & $c$ & G & $T$ & G & C & - & A & A & $T$ & A & G \\
\hline & H. gelipurpurascens (Y18836) & $T$ & A & $T$ & $A$ & C & $c$ & G & $T$ & G & C & - & A & C & $T$ & A & G \\
\hline & H. norwichensis (AJ549285) & $\mathrm{T}$ & A & $T$ & $A$ & C & C & $\boldsymbol{G}$ & $\mathrm{T}$ & G & C & - & A & C & $\mathrm{T}$ & A & G \\
\hline & H. roseosalivarius (Y18833) & $T$ & A & $T$ & $A$ & C & $c$ & G & $T$ & G & C & - & A & A & $T$ & A & G \\
\hline & H. rigui (DQ089669) & $T$ & A & $T$ & $A$ & C & $c$ & $\mathbf{G}$ & $T$ & G & C & - & A & C & $T$ & A & G \\
\hline & H. psychrophilus (GQ131579) & $\mathrm{T}$ & A & $T$ & $A$ & C & C & $\boldsymbol{G}$ & $\mathrm{T}$ & G & C & - & A & C & $\mathrm{T}$ & A & G \\
\hline & H. psychrotolerans (DQ177475) & $\mathrm{T}$ & A & $T$ & $A$ & C & $C$ & $G$ & $\mathrm{~T}$ & G & C & - & A & A & $\mathrm{T}$ & A & G \\
\hline & H. perfusus (HM032896) & $T$ & A & $T$ & $A$ & . & $c$ & G & $T$ & $\mathrm{~T}$ & C & - & A & A & $T$ & A & G \\
\hline & H. xinjiangensis (DQ888329) & $\mathrm{T}$ & A & $T$ & $A$ & C & $C$ & G & $T$ & G & C & - & C & A & $\mathrm{T}$ & A & G \\
\hline & H. yonginensis (GU808562) & $\mathrm{T}$ & A & $T$ & $A$ & C & $C$ & G & $\mathrm{T}$ & G & C & - & A & A & $\mathrm{T}$ & A & G \\
\hline & H. tibetensis (EU382214) & $T$ & A & $T$ & $A$ & C & $c$ & $G$ & $\mathrm{~T}$ & G & C & - & A & C & $T$ & A & G \\
\hline
\end{tabular}


Citation: Sathyanarayana Reddy G (2013) Phylogenetic Analyses of the Genus Hymenobacter and Description of Siccationidurans gen. nov., and Parahymenobacter gen. nov. J Phylogen Evolution Biol 1: 122. doi:10.4172/2329-9002.1000122

Page 5 of 9

\begin{tabular}{|c|c|c|c|c|c|c|c|c|c|c|c|c|c|c|c|c|c|}
\hline \multirow{2}{*}{ Clade3 } & Ph. deserti (EU325941) & C & A & $T$ & $\boldsymbol{A}$ & C & $c$ & $G$ & $T$ & G & G & - & A & A & G & $T$ & $T$ \\
\hline & Ph. ocellatus (Y18835) & C & A & $T$ & $\boldsymbol{A}$ & C & c & G & $\mathrm{T}$ & G & G & - & A & A & G & T & $\mathrm{T}$ \\
\hline & & \multicolumn{16}{|c|}{ Position of the nucleotide } \\
\hline & Species & 594 & 658 & 728 & 747 & 833 & 854 & 896 & 897 & 902 & 903 & 1019 & & 1275 & 1285 & 1286 & 1364 \\
\hline & E. coli (J01695) & $\mathrm{T}$ & C & A & A & G & $\mathrm{T}$ & C & c & G & G & A & G & $A$ & A & $\mathrm{T}$ & T \\
\hline \multirow{7}{*}{ Clade1 } & S. arizonensis (JX294485) & $T$ & A & A & $T$ & C & $T$ & C & c & $\mathbf{G}$ & G & A & $T$ & C & G & A & $T$ \\
\hline & S. glaciei (GQ454806) & $\mathrm{T}$ & A & A & $T$ & G & $\mathrm{T}$ & $\mathrm{T}$ & $C$ & $\mathbf{G}$ & A & A & $T$ & C & G & A & $T$ \\
\hline & S. antarcticus (EU155012) & $T$ & A & A & $T$ & G & $T$ & $\mathrm{~T}$ & $C$ & $\mathbf{G}$ & A & A & $T$ & C & G & A & $T$ \\
\hline & S. soli (AB251884) & $T$ & A & A & $T$ & G & $T$ & C & c & $\mathbf{G}$ & G & A & $\mathrm{T}$ & C & G & A & $T$ \\
\hline & S. metalli (HM032898) & $T$ & A & A & $\mathbf{T}$ & $\mathrm{C}$ & $T$ & C & $G$ & $c$ & G & A & $T$ & $T$ & G & A & $T$ \\
\hline & S. flocculans (HM032897) & $T$ & A & A & C & C & $T$ & C & G & $c$ & G & A & $\mathrm{T}$ & $\mathrm{T}$ & G & A & $\mathrm{T}$ \\
\hline & S. ginsengisoli (JN090860) & $T$ & A & A & $T$ & C & $T$ & C & $\mathbf{G}$ & $C$ & G & A & $\mathrm{T}$ & $T$ & G & A & $T$ \\
\hline \multirow{17}{*}{ Clade2 } & H. actinosclerus (Y17356) & $T$ & C & $T$ & G & G & $T$ & $T$ & $c$ & $G$ & A & A & $T$ & $T$ & A & C & $T$ \\
\hline & H. aerophilus (AJ276901) & $T$ & $\mathrm{C}$ & $T$ & G & G & $T$ & $T$ & $c$ & $\mathbf{G}$ & A & A & $T$ & $T$ & A & C & $T$ \\
\hline & H. algoricola (EU155009) & $T$ & $\mathrm{C}$ & $T$ & G & $\mathrm{C}$ & $\mathrm{T}$ & $T$ & c & $G$ & A & A & $\mathrm{T}$ & $T$ & A & C & $T$ \\
\hline & H. chitinivorans (Y18837) & $\mathrm{T}$ & C & $\mathrm{T}$ & $G$ & C & A & $T$ & c & $\mathbf{G}$ & A & A & $\mathrm{T}$ & $\mathrm{T}$ & A & C & $T$ \\
\hline & H. daecheongensis (EU370958) & C & C & $T$ & G & C & $\mathrm{T}$ & $T$ & $C$ & 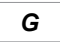 & A & A & $\mathrm{T}$ & $\mathrm{T}$ & A & C & $T$ \\
\hline & H. elongatus (GQ454797) & $T$ & $\mathrm{C}$ & $T$ & G & $\mathrm{C}$ & $\mathrm{T}$ & $T$ & c & $\mathbf{G}$ & A & A & $\mathrm{T}$ & $T$ & A & C & $T$ \\
\hline & H. fastidiosus (EU155015) & C & C & $T$ & G & C & $\mathrm{T}$ & $T$ & c & G & A & A & $\mathrm{T}$ & $\mathrm{T}$ & A & C & $T$ \\
\hline & H. gelipurpurascens (Y18836) & $\mathrm{T}$ & $G$ & $T$ & C & G & $\mathrm{T}$ & $T$ & $C$ & $\boldsymbol{G}$ & A & A & $\mathrm{T}$ & $\mathrm{T}$ & A & C & $T$ \\
\hline & H. norwichensis (AJ549285) & $T$ & $\mathrm{C}$ & $T$ & G & $\mathrm{G}$ & $\mathrm{T}$ & $T$ & c & $\mathbf{G}$ & A & A & $\mathrm{T}$ & $T$ & A & G & $T$ \\
\hline & H. roseosalivarius (Y18833) & $\mathrm{T}$ & G & $T$ & C & C & $\mathrm{T}$ & $T$ & $c$ & $G$ & A & A & $\mathrm{T}$ & C & A & C & $T$ \\
\hline & H. rigui (DQ089669) & $T$ & C & $T$ & G & G & $\mathrm{T}$ & $T$ & $c$ & $G$ & A & A & $T$ & $\mathrm{~T}$ & A & C & $\mathrm{T}$ \\
\hline & H. psychrophilus (GQ131579) & $T$ & $\mathrm{C}$ & $T$ & G & G & $T$ & $T$ & $C$ & $\mathbf{G}$ & A & A & $T$ & $T$ & A & A & $T$ \\
\hline & H. psychrotolerans (DQ177475) & $T$ & $\mathrm{C}$ & $T$ & G & $\mathrm{G}$ & $\mathrm{T}$ & $T$ & $C$ & $\boldsymbol{G}$ & A & G & $\mathrm{T}$ & $T$ & A & C & $T$ \\
\hline & H. perfusus (HM032896) & $\mathrm{T}$ & C & $T$ & G & $\mathrm{G}$ & $\mathrm{T}$ & $\mathbf{T}$ & $c$ & $\boldsymbol{G}$ & A & A & $\mathrm{T}$ & $\mathrm{T}$ & A & C & $T$ \\
\hline & H. xinjiangensis (DQ888329) & $T$ & C & T. & G & G & $\mathrm{T}$ & C & $C$ & $\mathbf{G}$ & G & A & $T$ & $T$ & A & A & $T$ \\
\hline & H. yonginensis (GU808562) & $T$ & $\mathrm{C}$ & $T$ & G & G & $\mathrm{T}$ & $T$ & $C$ & $\boldsymbol{G}$ & A & G & $\mathrm{T}$ & $T$ & A & C & $T$ \\
\hline & H. tibetensis (EU382214) & $\mathrm{T}$ & C & $T$ & $\mathrm{G}$ & $\mathrm{G}$ & $\mathrm{T}$ & $T$ & $c$ & $\boldsymbol{G}$ & A & A & $\mathrm{T}$ & $\mathrm{T}$ & A & G & $T$ \\
\hline \multirow{2}{*}{ Clade3 } & Ph. deserti (EU325941) & C & C & $T$ & G & $\mathbf{T}$ & C & C & $G$ & $c$ & G & G & C & A & G & A & C \\
\hline & Ph. ocellatus (Y18835) & C & C & $T$ & G & $\mathbf{T}$ & c & C & $G$ & $c$ & G & G & c & A & A & A & C \\
\hline
\end{tabular}

Table 1: Signature nucleotides of the 16S rRNA gene sequences that differentiate the genera Siccationidurans gen. nov.; Hymenobacter [9] and Parahymenobacter gen. nov. The numbering of nucleotide position is with respect to Escherichia coli 16S rRNA gene sequence (Acc. No. J01695); S. Siccationidurans; H. Hymenobacter; $\mathrm{Ph}$, Parahymenobacter; -,absence of a nucleotide; Positions in bold are the signature nucleotides of the genera.

bacter using MEME [17], only 1-2 unique signatures motifs were found to be unique. Out of 19, 11 motifs (ATGTGGTTTAATTCGATGAT [949-968], ATTTATTGGGTTTAAAGGGT [559-578], AGTAGGGAATATTGGGCAAT [356-375], AGCGGTGAAATGCATAGATA [687-706] and AACAGGATTAGATACCCTGG [781-800], GTGAAACTCAAAGGAATTGA [905-923], TAATACATGCAAGTCGAA [50-66], AACCTTACCTAGGCTAGAAT [977-995], ACAAAGCAAGGTGCTGCATG [1037-1057], AAGGCCTTCTGGGTTGTAAA [414-432]) were non-specific and identified other than Hymenobacter genera in BLAST. Motif TGAAATGCATAGATACCAT [692-710] was non-specific and restricted to 7 species of Clade1 to 3 of Hymenobacter. Four motifs were specific and identified the genus Hymenobacter in the EzTaxon and BLAST, of which motifs, AAGCTGGAATCACTAGTAAT [1332-1351], GTAAACGATGGATACTCGCT [812-831] and TTAGCGAAAGCGTTAAGTAT [858-877] were common to all three clades, and AAAGGCGGATTAATACCGCA [160-179] was present in Clade1 and Clade2. Motifs AAGGCTTTCTGAGTCGTAAA [414-432], TGACGGTACCTGAGGAATAA [480-499] and ATTAATACCGCATAACACT [168-185] and TAGTTAAAGAATTT [205-218] were uniquely identified among the species of Clade1, Clade2 and Clade3 respectively.

Based on the robust phylogenetic clustering of the genus Hymenobacter into three clades, Clade1, Clade2 and Clade3, 16S rRNA gene sequence similarity of less than $93.0 \%$, unique in silico restriction fragmentation pattern, signature nucleotides and signature motifs, two more genera were created to accommodate species of Cladel and Clade3, retaining the name Hymenobacter, sensu stricto, to represent 17 species of the Clade2. For members of Clade1 and Clade3, the names Siccationidurans gen. nov. and Parahymenobacter gen. nov. are proposed and species belonging to Clade1 and Clade 3 are transferred to their respective genera. In addition, Clade1 species are different from Clade 2 and Clade 3 in that they are negative for nitrate reduction and do not contain the fatty acid iso- $\mathrm{C}_{17: 0} 3-\mathrm{OH}$ (Table 2 ). The other diagnostic characteristics of the genera are listed in Table 2.

Seven species of Clade1, $H$. arizonensis [12], $H$. glaciei and $H$. antarcticus [13], $H$. soli [62], H. metalli, $H$. flocculans [63] and $H$. ginsengisoli [11] were transferred to the genus Siccationidurans gen. nov. as Siccationidurans arizonensis comb. nov., Siccationidurans glaciei comb. nov., Siccationidurans antarcticus comb. nov., Siccationidurans soli comb. nov., Siccationidurans metalli comb. nov., Siccationidurans flocculans comb. nov., and Siccationidurans ginsengisoli comb. nov. Siccationidurans soli $\mathrm{PB} 17^{\mathrm{T}}=\mathrm{LMG} 24240^{\mathrm{T}}=\mathrm{KCTC} 12607^{\mathrm{T}}$ was designated as the type species of the genus, first described species among Clade1. Clade2 contains 17 species; $H$. actinosclerus [64], H. aerophilus [65], $H$. algoricola, $H$. elongatus and $H$. fastidiosus [13], $H$. chitinivorans, $H$. gelipurpurascens and $H$. norwichensis [10], $H$. daecheongensis [66], $H$. roseosalivarius [9], H. rigui [67], H. psychrophilus [68], H. psychrotolerans [69], $H$. perfusus [63], H. tibetensis [70], $H$. xinjiangensis [71] and $H$. 
Citation: Sathyanarayana Reddy G (2013) Phylogenetic Analyses of the Genus Hymenobacter and Description of Siccationidurans gen. nov., and Parahymenobacter gen. nov. J Phylogen Evolution Biol 1: 122. doi:10.4172/2329-9002.1000122

\begin{tabular}{|c|c|c|c|c|c|}
\hline Characteristic & 1 & 2 & 3 & 4 & 5 \\
\hline Motility & - & - & - & + & - \\
\hline Pigment & Red-pink & $\begin{array}{l}\text { Pink or } \\
\text { Brick-red }\end{array}$ & $\begin{array}{l}\text { Pink-red or Brick } \\
\text { red or Pink }\end{array}$ & Pink & Pink \\
\hline \multicolumn{6}{|l|}{$\begin{array}{l}\text { Biochemical } \\
\text { characteristics }\end{array}$} \\
\hline Catalase & V & + & V & + & + \\
\hline Oxidase & V & + & V & + & + \\
\hline Urease & - & - & V & ND & - \\
\hline$\alpha$-galactosidase & V & - & V & - & + \\
\hline$\beta$-galactosidase & V & - & V & + & + \\
\hline Alkaline phosphatae & + & + & V & + & ND \\
\hline Nitrate reduction & - & + & V & - & - \\
\hline Starch hydrolysis & V & + & V & - & + \\
\hline Aesculin & V & - & V & + & ND \\
\hline Trypsin & V & - & V & + & ND \\
\hline Tween 80 & V & - & V & - & ND \\
\hline Casein & + & + & V & - & ND \\
\hline Gelatin & V & + & $\mathrm{V}$ & + & ND \\
\hline \multicolumn{6}{|c|}{ Fatty acid methyl esters } \\
\hline iso- $\mathrm{C}_{15: 0}$ & + & + & + & + & + \\
\hline anteiso- $\mathrm{C}_{15: 0}$ & + & + & + & + & + \\
\hline$C_{16: 1} \omega 5 c$ & + & + & + & - & + \\
\hline iso- $\mathrm{C}_{15: 0} 2 \mathrm{OH}$ & - & - & - & - & + \\
\hline iso- $_{15: 0} 3-\mathrm{OH}$ & - & + & + & $<5.0 \%$ & $<5.0 \%$ \\
\hline iso- $\mathrm{C}_{17: 0} 3-\mathrm{OH}$ & - & + & + & + & + \\
\hline Summed feature $3^{*}$ & + & + & + & + & - \\
\hline Summed feature $4^{*}$ & + & + & + & + & + \\
\hline Menaquinone & MK-7 & MK-7 & MK-7 & MK-7 & MK-7 \\
\hline Polar lipids & $\mathrm{PE}$ & $\mathrm{PE}$ & $\mathrm{PE}$ & $\mathrm{PE}$ & ND \\
\hline Mole \% DNA content & $58-70$ & $58-65$ & $54-65$ & $45-60$ & $40-48$ \\
\hline
\end{tabular}

Table 2: Phenotypic characteristics that differentiate the genera Siccationidurans gen. nov., and Parahymenobacter gen. nov., from other related genera 1. Siccationidurans gen. nov. ${ }^{1,2}$; 2. Parahymenobactergen. nov. ${ }^{3,4}$; 3. Hymenobacter $r^{3,5}$ 4. Pontibacter6; 5. Adhaeribacter ${ }^{7}{ }^{*}+$, positive; -, negative; ND, not determined; $\mathrm{V}$, variable; $\mathrm{PE}$, phosphatidyl ethanolamine; Summed feature 3 (iso- $\mathrm{C}_{150} 2-\mathrm{OH}$; and or $\mathrm{C}_{1.1} \omega 7 \mathrm{c}$ ); Summed feature 4 (iso- $\mathrm{C}_{17.1}$ I and/or anteiso- $\mathrm{C}_{17.1} \mathrm{~B}$ ). Data from ${ }^{1}$ Reddy and Garcia-Pichel [12]; ${ }^{2}$ Hoang et al. [11]; ${ }^{3}$ Buczolits et al. [10]; ${ }^{4}$ Zhang et al. [73]; ${ }^{5} \mathrm{Hirsch}$ et al. [9]; ${ }^{6}$ Nedashkovskaya et al. [20]; ${ }^{7}$ Rickard et al. [21].

yonginensis [72]. Clade3 containing two species, H. deserti [73] and H. ocellatus [10] were transferred to the genus Parahymenobacter gen. nov. as Parahymenobacter ocellatus comb. nov., and Parahymenobacter deserti comb. nov. The type species of the genus is Parahymenobacter ocellatus Myx $2105^{\mathrm{T}}=\mathrm{Txo1}^{\mathrm{T}}=\mathrm{DSM} 11117^{\mathrm{T}}=\mathrm{LMG} 21874^{\mathrm{T}}$.

Emended description of the genus Hymenobacter Hirsch et al. [9], emend. Buczolits et al. [10]

(Gr. n. humen, pellicle, thin layer; N.L. masc. n. bacter, rod; N.L. masc. n. Hymenobacter, a rod growing in thin layers). Members of the genus Hymenobacter are Gram-negative, strictly aerobic, pigmented, non-motile, non-spore forming and rod shaped. They are negative for indole production, arginine dihydrolase and urease, but positive for leucine arylamidase. Major polar lipids present are phosphatidylethanolamine (PE) and an unknown aminophospholipid (APL3), while the quinone system present is MK-7. Fatty acid profile consists of iso- and anteiso $\mathrm{C}_{15: 0}, \mathrm{C}_{16: 1} \omega 5 \mathrm{c}$, iso- $\mathrm{C}_{15: 0} 3-\mathrm{OH}$, iso- $\mathrm{C}_{17: 0}$ $3-\mathrm{OH}$, summed feature $3\left(\mathrm{C}_{16: 1} \omega 7 \mathrm{c} /\right.$ iso- $\left.\mathrm{C}_{15: 0} 2 \mathrm{OH}\right)$ and summed feature 4 (iso- $\mathrm{C}_{17: 1} \mathrm{I} /$ anteiso- $\mathrm{C}_{17: 1} \mathrm{~B}$ ). Species of the genus contain $\mathrm{C}(256)$, C (268), C-G (294-303), T-A (317-336), C-G (419-424), C (441), G (493), C-G (897-902), A (903), A (1285) as the signature nucleotides and TGACGGTACCTGAGGAATAA (480-499) as the signature motif in the $16 \mathrm{~S}$ rRNA gene sequences. The DNA G+C content of the genus ranges from 54 to $65 \mathrm{~mol} \%$. The genus currently comprises of seventeen species and Hymenobacter roseosalivarius AA-718 $=\mathrm{CIP} 106397^{\mathrm{T}}=\mathrm{DSM}$ $11622^{\mathrm{T}}$ is the type species.

\section{Description of Siccationidurans gen. nov.: Siccationidurans}

Sic.ca.ti.o.ni.du'rans. L. n. siccatioonis, drying, desiccation; L. part. adj. durans, resisting; N.L. masc. n. (N.L. masc. part. adj. used as a substantive) siccationidurans, desiccation-resisting. Cells of the genus Siccationidurans gen. nov. are Gram-negative, strictly aerobic, pigmented, non-motile, non-spore forming and rod shaped. Major fatty acids present (above 5.0\%) are iso- $\mathrm{C}_{15: 0^{\circ}}$, anteiso- $\mathrm{C}_{15: 0}, \mathrm{C}_{16: 0^{\prime}}$, $\mathrm{C}_{16: 1} \omega 5 \mathrm{c}$, summed feature $3\left(\mathrm{C}_{16: 1} \omega 7 \mathrm{c} /\right.$ iso- $\left.\mathrm{C}_{15: 0} 2 \mathrm{OH}\right)$, summed feature 4 (anteiso- $\mathrm{C}_{17: 1} \mathrm{~B} /$ iso- $\mathrm{C}_{17: 1} \mathrm{I}$ ) and $\mathrm{MK}-7$ is the sole respiratory quinine. They contain G-C (294-303), G (306), G-C (317-336), A (408), T-A (419-424), C (427), T (434), G-C/C-G (462-476), T (477), A (658), A (728), T (747), C-G/G-C (897-902), G (1285), A (1286) as signature nucleotides and lacks restriction sites for enzymes DpnI, MboI, Sau3A1 at position 209 and HaeIII at position 321 (positions with respect to Siccationidurans arizonensis). The genus possesses a unique 20 nucleotide long signature motif AAGGCTTTCTGAGTCGTAAA. Mole \% G+C DNA content of the genus ranges from 58.0 to $70.0 \%$. Siccationidurans soli $\mathrm{PB} 17^{\mathrm{T}}=\mathrm{KCTC} 12607^{\mathrm{T}}=\mathrm{LMG} 24240^{\mathrm{T}}$ is the type species.

\section{Description of Siccationidurans soli comb. nov.}

Siccationidurans soli (L. gen. n. soli, of soil, the source of the type strain)

\section{Basonym: Hymenobacter soli [62].} [62].

The species description is the same as that described by Kim et al.

\section{Description of Siccationidurans arizonensis comb. nov.}

Siccationidurans arizonensis (arizonensis: a.ri.zo.nen'sis.N.L. masc. adj. arizonensis, of or belonging to Arizona, one of the states of United States of America).

\section{Basonym: Hymenobacter arizonensis [12].}

The species description is the same as that described by Reddy and Garcia-Pichel [12].

\section{Description of Siccationidurans antarcticus comb. nov.}

Siccationidurans antarcticus (L. masc. adj. antarcticus, southern, by extension pertaining to Antarctic, referring to its isolation source).

Basonym: Hymenobacter antarcticus [13].

The species description is the same as that described by Klassen and Foght [13].

\section{Description of Siccationidurans glaciei comb. nov.}

Siccationidurans glaciei (L. gen. n. glaciei, of ice, referring to its isolation from a glacier).

Basonym: Hymenobacter glaciei [13].

The species description is the same as that described by Klassen and Foght [13].

\section{Description of Siccationidurans flocculans comb. nov.}


Citation: Sathyanarayana Reddy G (2013) Phylogenetic Analyses of the Genus Hymenobacter and Description of Siccationidurans gen. nov., and Parahymenobacter gen. nov. J Phylogen Evolution Biol 1: 122. doi:10.4172/2329-9002.1000122

Siccationidurans flocculans (N.L. part. adj. flocculans, flocculating, referring to the organism's trait to flocculate in liquid cultures).

Basonym: Hymenobacter flocculans [63]. al. [63].

The species description is the same as that described by Chung et

\section{Description of Siccationidurans metalli comb. nov.}

Siccationidurans metalli (L. gen. n. metalli, of a mine, from a mining area with metals).

Basonym: Hymenobacter metalli [63]. al. [63].

The species description is the same as that described by Chung et

\section{Description of Siccationidurans ginsengisoli comb. nov.}

Siccationidurans ginsengisoli (gin.sen.gi.so'li. N.L. n. ginsengum ginseng; L. n. solum soil; ginseng field, the source of the type strain)

Basonym: Hymenobacter ginsengisoli [11]. al. [11].

The species description is the same as that described by Hoang et

\section{Description of Parahymenobacter gen. nov.}

Parahymenobacter: Pa.ra.hy.me.no.bac'ter. Gr. prep. para, beside, near, like; N.L. masc. n. Hymenobacter, a bacterial genus name; N.L. masc. n. Parahymenobacter, beside Hymenobacter.

The genus Parahymenobacter gen. nov. contain the cells that are Gram-negative, strictly aerobic, pigmented, non-motile, non-spore forming and rod shaped. Catalase, oxidase, leucine arylamidase and alkaline phosphatase positive, urease, arginine dihydrolase and indole production negative, hydrolyzes casein, gelatin and starch. MK-7 is the major menaquinone, while phosphatidylethanolamine (PE) and an unknown aminophospholipid (APL3) are the dominating

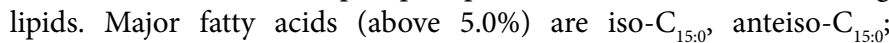
$\mathrm{C}_{16: 1} \omega 5 \mathrm{c}$, iso- $\mathrm{C}_{15: 0} 3-\mathrm{OH}$, iso- $\mathrm{C}_{17: 0} 3-\mathrm{OH}$, summed feature $3\left(\mathrm{C}_{16: 1} \omega 7 \mathrm{c} /\right.$ iso- $\mathrm{C}_{15: 0} 2 \mathrm{OH}$ ) and summed feature 4 (anteiso- $\mathrm{C}_{17: 1} \mathrm{~B} /$ anteiso- $\mathrm{C}_{17: 1} \mathrm{I}$ ). Signature nucleotides present are G (127), G (128), T (131), T (140), T (165), A (206), A (215), C (219), C (233), C (234), G-C (294-303), C (304), T-A (317-336), T (492), T (833), G-C (897-902), G (1019), C, A (1275), C (1364) and the signature motifs consists of the sequence ATTAATACCGCATAACACT (168-185) and TAGTTAAAGAATTT (205-218). Mole \% G+C DNA content of the genus ranges from 58 to 65. Parahymenobacter ocellatus $\mathrm{Myx} 2105^{\mathrm{T}}=\mathrm{Txo}^{\mathrm{T}}=\mathrm{DSM} 11117^{\mathrm{T}}=\mathrm{LMG}$ $21874^{\mathrm{T}}$ is the type species of the genus.

\section{Description of Parahymenobacter ocellatus comb. nov.}

Parahymenobacter ocellatus (L. masc. adj. ocellatus, showing little eyes, referring to the bright granules at the cell poles).

Basonym: Hymenobacter ocellatus [10].

The species description is the same as that described by Buczolits et al. [10].

\section{Description of Parahymenobacter deserti comb. nov.}

Parahymenobacter deserti (L. gen. n. deserti, of a desert).

Basonym: Hymenobacter deserti [73].

The species description is the same as that described by Zhang et al. [73].

\section{Acknowledgements}

The author acknowledges Jean P. Euzeby for suggesting the genera names and their epithet and Gundlapally Raga Reddy in preparing the manuscript.

\section{References}

1. Woose CR, Fox GE (1977) Phylogenetic structure of the prokaryotic domain The primary kingdom. Proc Natl Acad Sci U S A 74: 5088-5090.

2. Woose CR (1985) Why study evolutionary relationships among bacteria? In Evolution of Prokaryotes, Stackebrandt E, Schleifer KH (Ed.), Academy press, Inc, London, UK

3. Ash C, Farrow JAE, Wallbanks S, Collins MD (1991) Phylogenetic heterogeneity of the genus Bacillus revealed by comparative analysis of small subunitribosomal RNA sequences. Lett Appl Microbiol 13: 202-206.

4. Reddy GSN, Garcia-Pichel F (2009) Description of Patulibacter americanus sp. nov., isolated from biological soil crusts, emended description of the genus Patulibacter Takahashi et al. 2006 and proposal of Solirubrobacterales ord. nov. and Thermoleophilales ord. nov. Int J Syst Evol Microbiol 59: 87-94.

5. Stackebrandt E, Rainey FA, Rainey WN (1997) Proposal for a new hierarchic Classification System, Actinobacteria classis nov. Int J Syst Bacteriol 47: 479491

6. Anzai Y, Kim H, Park JK, Wakabayashi H, Oyaizu H (2000) Phylogenetic affiliation of the pseudomonads based on 16S rRNA sequence. Int J Syst Evol Microbiol 50: 1563-1589.

7. Krishnamurthi S, Chakrabarti T, Stackebrandt E (2009) Re-examination of the taxonomic position of Bacillus silvestris Rheims et al., 1999 and proposal to transfer it to Solibacillus gen. nov. as Solibacillus silvestris comb. nov. Int J Syst Evol Microbiol 59: 1054-1058.

8. Yoon JH, Kang SS, Lee KC, Lee ES, Kho YH, et al. (2001) Planomicrobium koreense gen. nov., sp. nov., a bacterium isolated from the Korean traditional fermented seafood jeotgal, and transfer of Planococcus okeanokoites (Nakagawa et al. 1996) and Planococcus mcmeekinii (Junge et al. 1998) to the genus Planomicrobium. Int J Syst Evol Microbiol 51: 1511-1520.

9. Hirsch P, Ludwig W, Hethke C, Sittig M, Hoffmann B, et al. (1998) Hymenobacter roseosalivarius gen. nov., sp. nov. from continental Antartica soils and sandstone: Bacteria of the Cytophaga/Flavobacterium/Bacteroides line of phylogenetic descent. Syst Appl Microbiol 21: 374-383.

10. Buczolits S, Denner EM, Kämpfer P, Busse HJ (2006) Proposal of Hymenobacter norwichensis sp. nov., classification of 'Taxeobacter ocellatus' 'Taxeobacter gelupurpurascens' and 'Taxeobacter chitinovorans' as Hymenobacter ocellatus $\mathrm{sp}$. nov., Hymenobacter gelipurpurascens sp. nov. and Hymenobacter chitinivorans sp. nov., respectively, and emended description of the genus Hymenobacter Hirsch et al. 1998. Int J Syst Evol Microbiol 56: 2071-2078.

11. Hoang VA, Kim YJ, Nguyen, NL, Yang, DC (2013) Hymenobacter ginsengisoli sp. nov., isolated from soil of a ginseng field. Int J Syst Evol Microbiol 63: 661 666.

12. Reddy GSN, Garcia-Pichel F (2013) Description of Hymenobacter arizonensis sp. nov. from the southwestern arid lands of the United States of America. Antonie van Leeuwenhoek 103: 321-330.

13. Klassen JL, Foght JM (2011) Characterization of Hymenobacter isolates from Victoria Upper Glacier, Antarctica reveals five new species and substantial nonvertical evolution within this genus. Extremophiles 15: 45-57.

14. Tamura K, Peterson D, Peterson N, Stecher G, Nei M, et.al. (2011) MEGA5 Molecular evolutionary genetics analysis using maximum likelihood, evolutionary distance and maximum parsimony methods. Mol Biol Evol 28 : 2731-2739.

15. Kimura M (1980) A simple method for estimating evolutionary rates of base substitutions through comparative studies of nucleotide sequences. J Mol Evol 16: $111-120$

16. Rohlf FJ (1993) NTSYS-pc v. 1.8., Numerical taxonomy and multivariate analysis system. 191. Setauket, Applied Biostatistics Inc, NY, USA.

17. Bailey TL, Williams N, Misleh C, Li WW (2006) MEME: Discovering and analyzing DNA and protein sequence motifs. Nucleic Acids Res 34: W369-W373.

18. Altschul SF, Gish W, Miller W, Myers EW, Lipman DJ (1990) Basic local alignment search tool. J Mol Biol 215: 403-410.

19. Chun J, Lee JH, Jung Y, Kim M, Kim S, et al. (2007) EzTaxon: A web-based 
Citation: Sathyanarayana Reddy G (2013) Phylogenetic Analyses of the Genus Hymenobacter and Description of Siccationidurans gen. nov., and Parahymenobacter gen. nov. J Phylogen Evolution Biol 1: 122. doi:10.4172/2329-9002.1000122

Page 8 of 9

tool for the identification of prokaryotes based on 16S ribosomal RNA gene sequences. Int J Syst Evol Microbiol 57: 2259-2261.

20. Nedashkovskaya OI, Kim SB, Suzuki M, Shevchenko LS, Lee MS, et al. (2005) Pontibacter actiniarum gen. nov., sp. nov., a novel member of the phylum 'Bacteroidetes', and proposal of Reichenbachiella gen. nov. as a replacement for the illegitimate prokaryotic generic name Reichenbachia Nedashkovskaya et al. 2003. Int J Syst Evol Microbiol 55: 2583-2588.

21. Rickard AH, Stead AT, O'May GA, Lindsay S, Banner M, et al. (2005) Adhaeribacter aquaticus gen. nov., sp. nov., a Gram-negative isolate from a potable water biofilm. Int J Syst Evol Microbiol 55: 821-829.

22. Ashelford KE, Chuzhanova NA, Fry JC, Jones AJ, Weightman AJ (2005) A least 1 in 20 16S rRNA sequence records currently held in public repositories is estimated to contain substantial anomalies. Appl Environ Microbiol 71: 77247736 .

23. Chakravorty S, Helb D, Burday M, Connell N, Alland D (2007) A detailed analysis of $16 \mathrm{~S}$ ribosomal RNA gene segments for the diagnosis of pathogenic bacteria. J Microbiol Methods 69: 330-339.

24. Swofford DL, Waddell PJ, Huelsenbeck JP, Foster PG, Lewis PO, et al. (2001) Bias in phylogenetic estimation and its relevance to the choice between parsimony and likelihood methods. Syst Biol 50: 525-539.

25. Zhang JY, Liu XY, Liu SJ (2009) Adhaeribacter terreus sp. nov., isolated from forest soil. Int J Syst Evol Microbiol 59: 1595-1598.

26. Wang Y, Zhang K, Cai F, Zhang L, Tang Y, et al. (2010) Pontibacter xinjiangensis sp. nov., in the phylum 'Bacteroidetes', and reclassification of Effluviibacter roseus as Pontibacter roseus comb. nov. Int J Syst Evol Microbiol 60: 99-103.

27. Xu M, Wang Y, Dai J, Jiang F, Rahman E, et al. (2012) Pontibacter populi sp nov., isolated from the soil of a Euphrates poplar (Populus euphratica) forest. Int J Syst Evol Microbiol 62: 665-670.

28. Dwivedi V, Niharika N, Lal R (2013) Pontibacter lucknowensis sp. nov., isolated from a hexachlorocyclohexane dump site. Int J Syst Evol Microbiol 63: 309-313.

29. Dastager SG, Raziuddin QS, Deepa CK, Li WJ, Pandey A (2010) Pontibacter niistensis sp. nov., isolated from forest soil. Int J Syst Evol Microbiol 60: 28672870.

30. Ludwig W, Strunk O, Klugbauer S, Klugbauer N, Weizenegger M, et al. (1998) Bacterial phylogeny based on comparative sequence analysis. Electrophoresis 19: $554-568$

31. Ivanova EP, Flavier S, Christen R (2004) Phylogenetic relationships among marine Alteromonas-like proteobacteria: Emended description of the family Alteromonadaceae and proposal of Pseudoalteromonadaceae fam. nov., Colwelliaceae fam. nov., Shewanellaceae fam. nov., Moritellaceae fam. nov., Ferrimonadaceae fam. nov., Idiomarinaceae fam. nov. and Psychromonadaceae fam. nov. Int J Syst Evol Microbiol 54: 1773-1788.

32. Monciardini P, Cavaletti L, Schumann P, Rohde M, Donadio S (2003) Conexibacter woesei gen. nov., sp. nov., a novel representative of a deep evolutionary line of descent within the class Actinobacteria. Int J Syst Evo Microbiol 53: 569-576.

33. Singleton DR, Furlong MA, Peacock AD, White DC, Coleman DC, et al. (2003) Solirubrobacter pauli gen. nov., sp. nov., a mesophilic bacterium within the Rubrobacteridae related to common soil clones. Int J Syst Evol Microbiol 53 485-490.

34. Takahashi Y, Matsumoto A, Morisaki K, Omura S (2006) Patulibacter minatonensis gen. nov., sp. nov., a novel actinobacterium isolated using an agar medium supplemented with superoxide dismutase, and proposal of Patulibacteraceae fam. nov. Int J Syst Evol Microbiol 56: 401-406.

35. Colwell RR (1970) Polyphasic taxonomy of the genus Vibrio: Numerical taxonomy of Vibrio cholerae, Vibrio parahaemolyticus, and related Vibrio species. J Bacteriol 104: 410-433.

36. Murray RGE, Brenner DJ, Colwell RR, De Vos P, Goodfellow M, et.al. (1990) Report of the Ad Hoc Committee on Approaches to Taxonomy within the Proteobacteria. Int J Syst Bacteriol 40:213-215.

37. Stackebrandt E, Frederiksen W, Garrity GM, Grimont PA, Kämpfer P, et al (2002) Report of the ad hoc committee for the re-evaluation of the species definition in bacteriology. Int J Syst Evol Microbiol 52: 1043-1047.

38. Vandamme P, Pot B, Gillis M, de Vos P, Kersters K, et al. (1996) Polyphasic taxonomy, a consensus approach to bacterial systematics. Microbiol Rev 60 407-438.
39. Young KD (2006) The selective value of bacterial shape. Microbiol Mol Biol Rev 70: 660-703.

40. Young KD (2007) Bacterial morphology: Why have different shapes? Curr Opin Microbiol 10: 596-600.

41. Justice SS, Hunstad DA, Cegelski L, Hultgren SJ (2008) Morphological plasticity as a bacterial survival strategy. Nat Rev Microbiol 6: 162-168.

42. Sousa AM, Machado I, Pereira MO (2011) Phenotypic switching: An opportunity to bacteria thrive, Science against microbial pathogens: communicating current research and technological advances. Formatexa. Méndez-Vilas (Ed.).

43. Gügi B, Orange N, Hellio F, Burini JF, Guillou C, et al. (1991) Effect of growth temperature on several exported enzyme activities in the psychrotrophic bacterium Pseudomonas fluorescens. J Bacteriol 173: 3814-3820.

44. Priyadarshini SRB, Mugeraya G, Sandhyavali MS (2012) Effect of media constituents on microbial enzyme activity. IJPCBS 2: 236-241.

45. Koga $Y$ (2012) Thermal adaptation of the archaeal and bacterial lipid membranes. Archaea 2012: 789652.

46. Scherer C, Müller KD, Rath PM, Ansorg RA (2003) Influence of culture conditions on the fatty acid profiles of laboratory-adapted and freshly isolated strains of Helicobacter pylori. J Clin Microbiol 41: 1114-1117.

47. Farrand SK, Taber HW (1974) Changes in menaquinone concentration during growth and early sporulation in Bacillus subtilis. J Bacteriol 117: 324-326.

48. Hiraishi A, Sugiyama J, Komagata K (1991) Simultaneous formation of menaquinones and demethylmenaquinones by Micrococcus varians IAM 12146 depending on cell growth media. Curr Microbiol 22: 53-58.

49. Saddler GS, Goodfellow M, Minnikin DE, O'Donnell AG (1986) Influence of the growth cycle on the fatty acid and menaquinone composition of Streptomyces cyaneus NCIB 9616. J Appl Microbiol 60: 51-56.

50. Corsaro MM, Lanzetta R, Parrilli E, Parrilli M, Tutino ML, et al. (2004) Influence of growth temperature on lipid and phosphate contents of surface polysaccharides from the antarctic bacterium Pseudoalteromonas haloplanktis TAC 125. J Bacteriol 186: 29-34.

51. Ray PH, White DC, Brock TD (1971) Effect of growth temperature on the lipid composition of Thermus aquaticus. J Bacteriol 108: 227-235.

52. Verheul A, Russell NJ, Van'T Hof R, Rombouts FM, Abee T (1997) Modifications of membrane phospholipid composition in nisin-resistant Listeria monocytogenes Scott A. Appl Environ Microbiol 63: 3451-3457.

53. Yano Y, Nakayama A, Ishihara K, Saito H (1998)Adaptive changes in membrane lipids of barophilic bacteria in response to changes in growth pressure. Appl Environ Microbiol 64: 479-485.

54. Caparrós M, Pisabarro AG, de Pedro MA (1992) Effect of D-amino acids on structure and synthesis of peptidoglycan in Escherichia coli. J Bacteriol 174: 5549-5559.

55. Mengin-Lecreulx D, van Heijenoort J (1985) Effect of growth conditions on peptidoglycan content and cytoplasmic steps of its biosynthesis in Escherichia coli. J Bacteriol 163: 208-212.

56. Horcajo P, de Pedro MA, Cava F (2012) Peptidoglycan plasticity in bacteria: stress-induced peptidoglycan editing by noncanonical D-amino acids. Microb Drug Resist 18: 306-313.

57. Takacs CN, Hocking J, Cabeen MT, Bui NK, Poggio S, et al. (2013) Growth medium-dependent glycine incorporation into the peptidoglycan of Caulobacter crescentus. PLoS One 8: e57579.

58. Reddy GSN, Manasa BP, Singh SK, Shivji S (2013) Paenisporosarcina indica sp. nov., a psychrophilic bacterium from Pindari Glacier of the Himalayan mountain ranges and reclassification of Sporosarcina antarctica Yu et al. 2008 as Paenisporosarcina antarctica comb. nov. and emended description of the genus Paenisporosarcina. Int J Syst Evol Microbiol 63: 2927-2933.

59. Shivaji S, Srinivas TNR, Reddy GSN (2013) Family Planococcaceae. The Prokaryotes. (4th Edn), Rosenberg E, DeLong EF, Thompson F, Lory S, Stackebrandt E (Eds.), Springer, USA.

60. Dai X, Wang YN, Wang BJ, Liu SJ, Zhou YG (2005) Planomicrobium chinense sp. nov., isolated from coastal sediment, and transfer of Planococcus psychrophilus and Planococcus alkanoclasticus to Planomicrobium as Planomicrobium psychrophilum comb. nov. and Planomicrobium alkanoclasticum comb. nov. Int J Syst Evol Microbiol 55: 699-702. 
Citation: Sathyanarayana Reddy G (2013) Phylogenetic Analyses of the Genus Hymenobacter and Description of Siccationidurans gen. nov., and Parahymenobacter gen. nov. J Phylogen Evolution Biol 1: 122. doi:10.4172/2329-9002.1000122

61. Maruyama T, Park HD, Ozawa K, Tanaka Y, Sumino T, et al. (2006) Sphingosinicella microcystinivorans gen. nov., sp. nov., a microcystindegrading bacterium. Int J Syst Evol Microbiol 56: 85-89.

62. Kim KH, Im WT, Lee ST (2008) Hymenobacter soli sp. nov., isolated from grass soil. Int J Syst Evol Microbiol 58: 941-945.

63. Chung AP, Lopes A, Nobre MF, Morais PV (2010) Hymenobacter perfusus sp. nov., Hymenobacter flocculans sp. nov. and Hymenobacter metalli sp. nov. three new species isolated from an uranium mine waste water treatment system. Syst Appl Microbiol 33: 436-443.

64. Collins MD, Hutson RA, Grant IR, Patterson MF (2000) Phylogenetic characterization of a novel radiation-resistant bacterium from irradiated pork: Description of Hymenobacter actinosclerus sp. nov. Int J Syst Evol Microbio 50: 731-734

65. Buczolits S, Denner EB, Vybiral D, Wieser M, Kämpfer P, et al. (2002) Classification of three airborne bacteria and proposal of Hymenobacter aerophilus sp. nov. Int J Syst Evol Microbiol 52: 445-456.

66. Xu JL, Liu QM, Yu HS, Jin FX, Lee ST, et al. (2009) Hymenobacter daecheongensis sp. nov., isolated from stream sediment. Int J Syst Evol Microbiol 59: 1183-1187.
67. Baik KS, Seong CN, Moon EY, Park YD, Yi H, et al. (2006) Hymenobacter rigui sp. nov., isolated from wetland freshwater. Int J Syst Evol Microbiol 56: 2189-2192.

68. Zhang DC, Busse HJ, Liu HC, Zhou YG, Schinner F, et al. (2011) Hymenobacter psychrophilus sp. nov., a psychrophilic bacterium isolated from soil. Int J Syst Evol Microbiol 61: 859-863.

69. Zhang G, Niu F, Busse HJ, Ma X, Liu W, et al. (2008) Hymenobacter psychrotolerans sp. nov., isolated from the Qinghai--Tibet Plateau permafrost region. Int J Syst Evol Microbiol 58: 1215-1220.

70. Dai J, Wang Y, Zhang L, Tang Y, Luo X, et al. (2009) Hymenobacter tibetensis sp. nov., a UV-resistant bacterium isolated from Qinghai-Tibet plateau. Syst Appl Microbiol 32: 543-548.

71. Zhang Q, Liu C, Tang Y, Zhou G, Shen P, et al. (2007) Hymenobacter xinjiangensis sp. nov., a radiation-resistant bacterium isolated from the desert of Xinjiang, China. Int J Syst Evol Microbiol 57: 1752-1756.

72. Joung Y, Cho SH, Kim H, Kim SB, Joh K (2011) Hymenobacter yonginensis sp. nov., isolated from a mesotrophic artificial lake. Int J Syst Evol Microbio 61: 1511-1514.

73. Zhang L, Dai J, Tang Y, Luo X, Wang Y, et.al. (2009) Hymenobacter desert sp. nov., isolated from the desert of Xinjiang, China. Int. J Syst Evol Microbiol 59: 77-82 